\title{
INFORMATION SYSTEMS OUTSOURCING RISKS: A STUDY OF LARGE FIRMS
}

\section{AUTHOR'S BIOGRAPHY}

Reyes Gonzalez (mr.gonzalez@ua.es) is a Senior Lecturer in Business Management and Information Systems at the University of Alicante. Her current research interests are Information Systems Management, E-Business and Outsourcing Processes. She has published articles in several journals, e.g. Information and Management, Information Technology and People, Logistics Information Management, Total Quality Management, and The International Journal of Educational Management.

Jose Gasco (jl.gasco@ua.es) is a Senior Lecturer in Business Management and Human Resources at the University of Alicante. His current research interests include Human Resources and Information Systems Outsourcing. He has published articles in several journals, namely, Revue Internationale P.M.E., Direction et Gestion des Entreprises, Corporate Communications: an International Journal, The International Journal of Public Sector Management, Business Process Management Journal, Total Quality Management, Information Technology and People, and Logistics Information Management.

Juan Llopis (juan.llopis@ua.es) is a Professor of Business Organisation at the University of Alicante. Among his current research lines stand out Organisational Culture, Human Resources, Quality Management, and Information Systems Management. He has published articles in journals like Information and Management, Total Quality Management, Journal of High Technology Management Research, Corporate Communications: An International Journal, Information Technology and People, Logistics Information Management Journal, and International Journal of Value-Based Management.

\section{CORRESPONDING AUTHOR}

Reyes Gonzalez. Department of Business Organisation. University of Alicante. Carretera San Vicente-Alicante. Zip Code: 03080. Alicante. SPAIN. Telephone and fax: 3496590 36 06. e-mail: mr.gonzalez@ua.es. 


\title{
INFORMATION SYSTEMS OUTSOURCING RISKS: A STUDY OF LARGE \\ FIRMS
}

\begin{abstract}
Despite the considerable growth of Information Systems (IS) outsourcing in recent years, this trend is still the object of strong criticism. This study has as its aim to show the main risks computer outsourcing entails in the case of the largest Spanish firms. In order to achieve that aim, we have reviewed the previous literature on this topic and later analysed the results of a survey carried out using a questionnaire that was answered by 357 firms.
\end{abstract}

According to the firms under analysis, the main concern in relation to IS outsourcing is the excessive dependence on the provider this type of contract can generate. Nevertheless, some characteristics of firms (mainly their size) determine to some extent what risks are seen as the most relevant. The conclusions also suggest that total outsourcing can turn out to be a very dangerous strategy, mainly due to the dependence it creates. This is why IS managers should consider other alternatives such as having multiple providers or resorting to selective outsourcing.

\section{KEYWORDS}

Information Systems Management, Outsourcing, Risks, Survey

\section{INTRODUCTION - THE RISE OF INFORMATION SYSTEMS OUTSOURCING}

Information Systems (IS) outsourcing can be defined as the significant contribution made by external providers of physical and/or human resources, associated either with all components or with IT infrastructure specific components in the user's organisation (Loh and Venkatraman, 1992:9). Such a contribution is confined to a contractual agreement that can even entail the assumption of managerial responsibilities linked with the provision of Information Technology (IT) services by the supplier (Clark, Zmud and McCray, 1995:223). 
The term outsourcing appeared not long ago, in the 1990s (Tayntor, 2001). However, externally contracted computer services are nothing new. Shared-time services, for example, were a common practice in firms during the 1960s and 1970s (Grover and Teng, 1993:34; Ketler and Walstrom, 1993:449). Nevertheless, it is the nature of outsourcing that has changed: while small firms frequently resorted to these services seeking to obtain capacities that were internally unavailable or impossible, at present, even the largest firms with mature IS departments have outsourced (Grover, Cheon and Teng, 1994:36; Teng, Cheon and Grover, 1995:77). What is more, whereas in the past outsourcing was relegated to non-information-intensive sectors where the IS could not play a central role in terms of firm competitiveness, nowadays it is possible to find outsourcing agreements in high-information-content sectors (Alpar and Saharia, 1995:203; Ang and Cummings, 1997:236; Hurst and Hanessian, 1995:103; McLellan, Marcolin and Beamish, 1995:310).

IS outsourcing has experienced a considerable growth in recent years, so much so that some authors suggest we find ourselves in the Outsourcing Era (King, 2001:15). Judging by the forecast figures offered by some computer market analysts, this growth also seems to be guaranteed at least in the near future. Thus, according to the forecast made by the Yankee Group in October 2002, the global outsourcing market for that year would reach a figure between 85 and 95 trillion US dollars, with a foreseen growth rate located between 10 and 12\% for the four following years (The Yankee Group, 2003). It can also be observed that these services are spreading geographically, from North America, the United Kingdom and Australia to Western Europe, South America and some countries in South East Asia, among them Japan (Moran, 1999:1). Besides, the scope and range of services being outsourced are also growing (Currie, 1998:169), as is illustrated by the promotion of the following: 
- BPO (Business Process Outsourcing), a relatively new concept that implies combining IS outsourcing with support or consulting for the business functions outsourcing refers to (Currie, 1998:169).

- ASP (Applications Service Providers) is also developing (Smith, 2002:451) -ASPs are third-party service firms which deploy, manage and remotely host software applications through centrally located services under a rental or lease agreement(Currie and Seltsikas, 2001:123; Kearney, 2000:37; Yang and Huang, 2000:227).

- Web and eBusiness Outsourcing, where vendors are contracted to provide web-based applications that enable a firm to enter the eBusiness era, is another growing area within IS outsourcing (Hirschheim and Dibbern, 2002:7).

- Global Outsourcing, which consists in developing software in foreign countries with highly-trained computer staff and comparatively very low salaries. India is the world's leader in the field of global outsourcing (Chen and Lin, 1998; Heeks et al., 2001).

The growth of outsourcing in our nearest environment -Western Europe- has also been very significant since the early 1990s. A 1998 IDC (International Data Corporation) survey revealed that outsourcing expenses had passed from 22.666 billion US dollars in 1996 to 33.616 billion in 2001. Among the factors that may have caused this growth, and apart from human capital shortages and the growing competitiveness in European firms, we should also mention the process of adaptation to the European Monetary Union firms have had to go through (Baldwing, Irani and Love, 2001:16).

We could suggest another set of diverse reasons that account for the growth of computer outsourcing; for instance, the top management's scepticism about the value of Information Systems (Lacity and Hirschheim, 1993a:17) and the uncertainty that surrounds them, making it difficult to anticipate whether a specific technology will or will not prove profitable (Loh and Venkatraman, 1992:17). Pushed by the spectacular positive results obtained by some companies that were pioneers of this trend, many 
firms have succumbed to the fashion effect (Lacity and Hirschheim, 1993b:74). Another reason is that firms tend to abandon their diversification strategies and have started to focus on their critical competences. In this context, firms see IT as a non-basic activity (King, 2001:15; Lacity, Willcocks and Feeny, 1996:13) and thus have decided to concentrate their internal skills and competences on areas that provide more added value (Chen and Lin, 1998:10). IT cost control is another common justification (Ching, Holsapple and Whinston, 1996:179; Clark, Zmud and McCray, 1995:228), as outsourcing makes it possible to reduce the IS department's size and transform fixed costs into variable ones. We should equally mention among the reasons for this trend the fast evolution of technology that subjects firms to a high risk of technological obsolescence which, thanks to outsourcing, is passed on to the firm supplying these services.

We could even argue that the phenomenon of globalisation has had a role in the growth of IS outsourcing, mainly in two ways:

a) The tendency of firms to locate their productive processes in places where production factors are cheaper becomes evident in what has come to be known as Global Outsourcing, which consists in developing software in foreign countries with highly-trained computer staff and comparatively very low salaries. (India is the world's leader in this area of global outsourcing (Heecks et al., 2001)).

b) The growing acceptance of the Internet as a means of communication has undoubtedly exerted an influence on the rise of outsourcing too (Yang and Huang; 2000:227), specially as far as applications outsourcing -the tendency to develop applications through the Internet instead of installing them in a local environment- is concerned (Marchand and Jacobsen, 2001).

However, according to Lacity and Willcocks (1995:226-228), the unique, different nature of IT usually places customers in a disadvantageous position with respect to IS outsourcing providers, due to the following reasons:

1. IT evolves so fast that the degree of uncertainty accompanying every outsourcing decision is very high. 
2. IT is involved in every business function, which is why an idiosyncratic knowledge of the organisation is required to carry out many IT activities.

3. The costs derived from replacing one IT provider for another are very high, which is why fostering competition to discourage providers' opportunism is complicated.

Customers often lack experience in the signature of outsourcing contracts. This is not the case for providers (Ketler and Walstrom; 1993:457). Due to this information asymmetry, providers can favour their own position much better.

For this reason, and despite the growth of IS outsourcing and the multiple reasons justifying it, this trend is still the object of strong criticism sometimes. This is why the present paper seeks to identify the risks perceived to be the most relevant in IS outsourcing, from the customer's point of view. With that aim in mind, we will firstly review the literature on IS outsourcing risks, after which we will show the methodology, the main results and the conclusions of an empirical piece of work based on a survey carried out among the IS managers of the largest Spanish firms. The results will not only tell us the level of importance of the said risks in the firms under analysis, but also will help us to try and determine whether or not those risks are conditioned by the outsourcing level or the diverse characteristics of firms (like sector and size) and their IS departments.

\section{OUTSOURCING RISKS IN INFORMATION SYSTEMS LITERATURE}

IS outsourcing is a managerial decision that entails various risks and problems, so much so that numerous authors have identified an associated risk for each advantage suggested. Firstly, we can encounter problems derived from the dependence this service generates. The dependence results from the fact that, in practice, firms find it difficult to quantify and define the information services they need, and besides, those services tend to evolve over time. Therefore, if these services had not been agreed in the original contract, they would have to be charged with an additional rate, thus increasing the total costs (Fowler and Jeffs, 1998:121); or internal improvements in the customer firm's 
IS might be neglected (Glass, 1996:90). This is why Lacity and Hirschheim (1993b:76) state that external providers are not strategic partners, as the interest in profits is not shared. In other words, when the customer's costs increase, the same happens to the provider's profits. Along the same lines, Guterl (1996:80) suggests that providers would rather customers had more additional costs, not fewer.

The loss of critical skills and competences is another relevant problem. When a service is outsourced, the customer loses his understanding of the service over time. Even though the provider supplies innovative services to the customer, a large part of the new knowledge required remains in the hands of the provider and cannot be transferred to the customer. Worse than that, the firm can lose its capacity to be up to date with technological breakthroughs (Clark, Zmud and McCray, 1995:231). Therefore, the customer needs to retain certain know-how and internal capacities in both technical and managerial areas if he wants to handle the outsourcing relationship properly (Willcocks and Lacity, 1999:177). Retaining these capacities is the best way to identify and evaluate potential outsourcing risks and also to perform practices that can mitigate those risks (Willcocks, Lacity and Kern, 1999:310).

An additional difficulty has to do with the qualification of the provider's staff. Although in theory outsourcing provides access to technical knowledge and IS specialists' expertise, what very often happens in practice is that the outsourcing firm is supported by the same staff as before (Fowler and Jeffs, 1998:122; Glass, 1996:89), as these staff have been transferred from the customer firm to the service-providing firm. Lacity and Hirschheim (1993b:78) warn that many of the outsourcing firms feel they have suffered losses in business knowledge and experience because providers send their most qualified workers to get new customers from other firms in the sector once they have achieved the contract. Besides, providers hardly ever take the initiative when it comes to business strategies; they prefer to follow specific instructions instead. 
The provider's lack of compliance with the contract is another possible risk. This problem is inherent to any contract: whenever an agent performs tasks for a principal, the principal always runs the risk of the agent not completing the task as expected or of being less vigilant than the principal would be (Clark, Zmud and McCray, 1995:230). Besides, in the case of IS outsourcing, customers' needs may not be properly met, and an inadequate task priority may be established, above all because the provider does not fully understand what the business is all about (Martinsons, 1993:21; Glass, 1996:90).

What is more, an unclear cost-benefit relationship might exist within IS outsourcing; after all, performing a cost/benefit analysis for outsourcing is no easy matter. Taking into account all relevant factors and translating them into monetary values is not easy either. For example, some issues include determining how to compare and translate the potentially better service of an outsourcing vendor with the service provided by the internal IS department, and deciding how to measure in economic terms the consequences of an outsourcing vendor failing to deliver products or delivering unacceptable products (Gupta and Gupta, 1992:49). Before these difficulties, many firms admit that their decision to outsource is only based on the costs of outsourcing, and not on its benefits (Clark, Zmud and McCray, 1995:230), seeing as costs exclusively those fixed in the contract.

Although one of the main theoretical objectives of outsourcing is to control IS costs or flexibilise them by making them become variable, outsourcing may have hidden costs, such as those derived from dismissing or transferring staff, the transfer of licences by software vendors, etc. These costs are mainly due to ambiguities in the contract, e.g. failing to define present and future IT requirements; applying poor recruitment practices; not allowing providers to obtain reasonable profits and being unable to create mechanisms that protect prices in contingency cases (Willcocks, Lacity and Fitzgerald, 1995:339). Summing up, the hidden costs of outsourcing could be the following (Barthélemy; 2001:61-66): a) vendor search and contracting - many enterprises underestimate the expense associated with identifying and evaluating suitable IT 
vendors, selecting a finalist, and negotiating as well as drafting the contract, $b$ ) transitioning to the vendor - it can take months before the vendor knows as much as the internal IT department, $c$ ) costs related to provider management - which imply, amongst other things, verifying that IT vendors fulfil their contractual obligations, bargaining with them, and finally, negotiating any contract changes required, and $d$ ) transition costs after outsourcing - these costs come from switching vendors or resuming IT activities internally.

We should mention possible security issues, above all when a provider has to serve several direct competitors, which means having to keep confidentiality about the information corresponding to all of them (Grover, Cheon and Teng, 1994:38; Lacity and Hirschheim, 1993a:24). The security of the IS services outsourced will depend on the providing firm, which is why policies and procedures must be negotiated during the outsourcing contract signature process to ensure that IS security objectives (effectiveness, efficiency, adequacy, integrity, validity, authorisation, privacy) continue to be fulfilled (Fink, 1994:5).

Another risk is the oft-mentioned irreversibility of the outsourcing decision (Fink, 1994:5), especially if the user has got rid of the technical and human infrastructure needed to reconstruct his IS in house (Barthélemy, 2001:67; Fowler and Jeffs, 1998:121). There are three main reasons for this irreversibility: the high costs involved in reconstructing the IS department, the difficulty to attract the necessary staff, and the amount of time required (Clark, Zmud and McCray, 1995:231).

Outsourcing generates various staff-related problems. Therefore, the customer firm will face the possible opposition of the IS staff, who see outsourcing as a threat to their working position. IS staff may find themselves before a dismissal, a retraining period, or a transfer to the service-providing firm (Grover, Cheon and Teng, 1994:38). This uncertain situation creates anxiety and a feeling of insecurity that may lead to a 
decrease in employee productivity during the period prior to the signature of the contract or even after the contract has been signed (Palvia, 1995:270).

When only some staff members are transferred from the customer firm to the provider firm, it has been checked that problems related to lack of motivation arise among those staying in the customer firm. These professionals probably feel offended because they think they are not good enough to belong to a specialist firm like the computer service provider (Willcocks and Fitzgerald, 1996:287). On the other hand, those who are transferred from one firm to another may suffer various changes that can go from keeping their seniority or any other favourable condition to the need to adapt to a new corporate culture. The status of the IT executives who remain in the customer firm usually improves (Martinsons, 1993:21), but they must reorient their competence (Corbett; 1994:20-21), focusing on external relationships management and dedicating much less time to operations management.

Finally, we can refer to the inability to adapt to new technologies. In theory, access to leading-edge technology is a persuasive argument in support of IS outsourcing, as a firm can enjoy the latest technology without the lead time that is customarily required for inhouse development (Palvia, 1995:269). Outsourcing vendors can quickly adapt to machine upgrades and new software releases (Lacity and Hirschheim, 1993a:20). In practice, though, if providers do not find benefits in the adoption of new technologies, they could become reluctant to adopt them, in an attempt to make the service they offer as profitable as possible. What is more, if the outsourcing contract does not include a clause relative to the future technological evolution, that evolution will not be completed (Glass, 1996:90).

All these risks will become greater if customers opt for total outsourcing. Therefore, IS managers should consider other alternatives such as resorting to selective outsourcing or outsourcing with multiple providers (Currie, 1998:171). With selective outsourcing, 
firms can retain the internal knowledge required to handle the outsourcing provider or even to revert the outsourcing process. With the option of multiple providers, the customer firm can negotiate outsourcing contracts with multiple providers differentiated by competence, experience and market position (Cross, 1995:96), thus making the different providers' skills complementary. However, even these strategies entail some risks. Cross (1995:96), for instance, points out that it is difficult to manage and coordinate the work of several providers. In turn, Loh and Venkatraman (1992:11) suggest that it is not easy to specify each provider's responsibilities either, especially when the outsourced processes are interdependent. Finally, Currie and Willcocks (1998:141) remind us that managing and co-ordinating multiple contracts is very time-consuming.

Other practices that would surely help to reduce risks require a full understanding of the nature of the work being outsourced, signing short-term contracts, demanding up-todate documentation about those contracts, and also have to do with the customer's ability to retain the skills and competences needed to ensure that contracts add value to profits (Earl, 1996:24; Currie, 1998:179, Hurst and Hanessian; 1995:107). 


\section{RESEARCH METHODOLOGY}

After identifying IS outsourcing risks in the literature, we will explore how these risks apply to the largest Spanish firms. The reason why we decided that the target population in our outsourcing study should be formed by the largest Spanish firms is similar to that provided by Fink and Shoeib (2003: 305) in the research they carried out in Australia: since no previous data on IS outsourcing in Spain were available, we could not establish population characteristics for our study. Instead, we decided to do a survey on large Spanish organisations, assuming that they would have large IT installations and, therefore, would have greater knowledge and experience with IT outsourcing.

In order to determine our target population, we used the directory Las 5.000 mayores empresas (The 5,000 largest firms) of Actualidad Económica magazine, which was collated with other databases largely used in business studies like Duns and Bradstreet's 50.000 Principales Empresas Españolas (the 50,000 main Spanish firms). Among the 5,000 firms with the highest sales, we tried to find in the list of the first database mentioned above which ones had the same telephone numbers and addresses, as this was a symptom revealing that both the IS manager and the structure itself could coincide. Once that information was known to us, we decided to send the questionnaire only to the firm which, having the same telephone number and address as others, showed the highest sales.

In this way, we eliminated 584 firms, after which our final database consisted of 4,416 firms, to which was sent a questionnaire along with a stamped addressed envelope for the questionnaire to be returned. We had to face a problem, namely that field studies based on surveys about IS outsourcing do not proliferate, case studies being more common (Aubert, Rivard and Patry; 1996; Baldwing, Irani and Love, 2001; Huber, 1993; Kern and Willcocks, 2000; Kern and Willcocks, 2002; Lacity and Hirschheim, 1993a; 1993b; Lacity and Willcocks, 1997; Lacity, Willcocks and Feeny, 1996; Loebbecke and Jelassi, 1999; McLellan, Marcolin and Beamish, 1995; Palvia, 1995; Willcocks and Choi, 1995; Willcocks, Fitzgerald and Lacity, 1996; Willcocks, Lacity and Kern, 1999). 
However, on the basis of previous literature about this matter, we prepared a questionnaire draft that was later subjected to a pilot test and a pre-test. 5 out of the 19 questions of the final questionnaire were used in this study, as this paper is part of a larger empirical study which deals with a wide range of aspects related to IS outsourcing (see APPENDIX). The questionnaire's addressee was the IS manager of the firms included in the final database. A new inconvenience arose here, because unlike what happens in other countries, no listings of these managers are available in Spain, which means that the addressee's identity was unknown.

The information obtained in the questionnaire was later elaborated using the statistical program SPSS for Windows and treated with univariant and multivariant statistical methods. Table I shows the study specifications.

Take in TABLE I

357 valid answers were obtained, which represents an $8 \%$ ratio. This ratio is acceptable if we bear in mind that obtaining an answer in surveys carried out among executives is problematic, particularly in surveys done to IS executives. This is so because the rapid technological change, the considerable investments firms have made on IT, and the great interest aroused by outsourcing have made these executives become the common target of many surveys (Poppo and Zenger, 1998:862). The firms which answered the questionnaire correctly are representative of the total population in terms of sales and sector $^{1}$.

\section{RESULTS}

We will now present the results of empirical work; firstly, we are going to show some general features of the firms, such as their outsourcing level or the size and characteristics of their IS department. Thanks to these data, we will be able to check, in the following subsection, what risks are involved in outsourcing, and whether these risks

\footnotetext{
${ }^{1}$ A $\mathrm{T}$ test was used to verify if firms which answered the survey and those which did not answer have different sale mean values. The $\mathrm{T}$ had a value of -1.699 and the significance level was 0.089 . A Chi-square test was used to see the relationship between the industrial sector the firm belongs to and the fact that it did or did not answer the questionnaire. The Chi value was 3.8 and the significance level was 0.151 . This implies that there is a non-response bias in relation to these two variables.
} 
are influenced by the above-mentioned features. We will finally provide a typology of firms, according to which risks are the most important for outsourcing.

\section{General characteristics of the firms}

Table II shows the outsourcing levels of the target firms along with some of their general features. The fictitious variable called "outsourcing" reflects the sum of the outsourcing percentages of each IS activity: if this sum equals zero, then there is no outsourcing; on the contrary, if the result of this sum is more than zero, then outsourcing exists ${ }^{2}$. We check that IS outsourcing is a widespread phenomenon, since only $14.3 \%$ of the interviewed firms have outsourced no IS services. The fictitious variable "outsourcing level" will help us to determine if firms' higher or lower outsourcing level conditions the risks they take when they decide to outsource their IS services. Thanks to the way in which this variable was designed, a fair distribution of firms with outsourcing levels above and below average is possible, because the median was used as the cut-off measure.

The size of a firm can be measured by number of employees and sales. Table II shows that the interviewed firms are very large with respect to these two variables, since the lowest percentages are found in the smallest firms (only $6.2 \%$ of them have between 0 and 50 employees and $10.1 \%$ turn over up to 5 billion pesetas, ca. 30 million $€$.).

Most of the interviewed firms belong to the Industrial sector (58.8\%), followed by the Service sector, in which one third of the firms are included. We have detected that $8.1 \%$ of the answers came from firms belonging to the Financial Institutions and Insurance sector.

Despite the size of firms, IS departments do not have a large staff volume. As is shown in Table II, most firms have between 1 and 10 employees, and only very few have IS departments with more than 100 employees. The part of the budget firms allocate to IS

\footnotetext{
2 This information is obtained from question 1 in the questionnaire (see APPENDIX). Nevertheless, this paper only analyses whether or not a firm outsources some IS activity, without specifying any activity in particular.
} 
is equally quite low if we compare it with the firm's total budget. It can also be seen in the same table that most firms dedicate between 0 and $4 \%$ of their budgets to IS, and only very few dedicate more than to $11 \%$ to this department, the maximum budget percentage allocated to IS being $30 \%$ (we must point out that the question referring to the percentage of the budget dedicated to IS was the least often answered one in the whole survey, which means that comments about this issue must be treated with caution). In short, both the IS department staff and the percentage of the budget allocated to this function prove that, regardless of firm size, only few human or financial resources are assigned to these departments.

\section{Take in TABLE II}

\section{Outsourcing risks}

Table III shows the risks involved in IS outsourcing. We must say that, in the corresponding question, and following the lines of previous works (Collins and Millen, 1995:9), interviewees were asked to specify the three risks they considered to be the most important out of a list that had previously been given to them ${ }^{3}$. That list was based on the review of the literature presented in a previous section of this paper ${ }^{4}$ The resulting variables were consequently dichotomical, with a zero value when a specific risk was not mentioned, and a one value when it was. $\mathrm{N}$ appears in the table standing for the number of times interviewees placed a particular risk among this 'top three'. The excessive dependence on the provider this contract may generate is very clearly identified as the main hindrance. Other relevant, although much less often mentioned drawbacks are the possible loss of competence by the customer and the dubious qualification level of the provider's staff. Curiously, the last problem in order of importance is the provider's inability to adapt to new technologies. In other words, doubts do not refer to technical aspects, but to the provider's personal (human) characteristics. Another relatively surprising result has to do with the fact that the potential opposition of the IS service staff appears as one of the least valued risks, even though the outsourcing contract may put those employee's jobs in danger.

\footnotetext{
${ }^{3}$ We know this means forcing interviewees to identify three risks, but we must underline that questionnaires in which less than three risks or even none were identified were considered valid.

${ }^{4}$ The order in which we presented the said risks in the section dedicated to the literature review is identical to the ranking shown in Table III, which makes it easier to establish a relationship between the theoretical review and the results obtained.
} 


\section{Take in TABLE III}

We then carried out another series of tests which had to make clear whether or not these risks were closely related to the firm's characteristics. In first place, and regarding the relationship between outsourcing level and outsourcing risks, we can identify three risks as undoubtedly dependent on outsourcing level (see Table IV):

- The firms that outsource the most are also the ones that most fear the dependence on the provider that is generated.

- The firms that outsource the most are also the ones that most fear the IS staff's possible opposition.

- They are equally the most concerned about the potential security problems outsourcing may generate.

\section{Take in TABLE IV}

As for the influence of size on outsourcing risks, we firstly analysed if the number of employees in the firm has a bearing on the development of those risks. In this case, we have detected quite a few statistical dependence relationships. Firms with higher numbers of workers show more concern about the qualification of the providing firm's staff, about the possible opposition to outsourcing of their IS department's staff, and about the unclear relationship between costs and benefits. In contrast, firms with fewer workers are above all concerned about dependence on the provider and potential security problems (see Table V).

\section{Take in TABLE V}

We also found some dependence relationships between the most frequent outsourcing risks and firm sales (see Table VI).

\section{Take in TABLE VI}

Firms with the highest sales are the ones which most fear the loss of critical skills and competences as well as potential staff opposition. Instead, those with lower sales are mostly concerned about the hidden costs of contracts and the dependence on the provider. Therefore, the group of smaller firms (in terms of numbers of workers and sales) especially fear dependence on the provider, while greater firms show reluctance to outsourcing due to their staff's opposition. 
Outsourcing risks are the same for the different firms, regardless of the activity sector they belong to, as can be seen in Table VII.

\section{Take in TABLE VII}

However, Table VIII shows the existence of a relationship between these risks and the IS department staff's size. Thus, we can say, for instance, that while firms with fewer employees in the department are the ones that most fear an excessive dependence on the provider, those with a higher number of employees are above all worried about the risk of losing critical skills and competences in their IS department and about the development of an unclear cost-benefit relationship.

Take in TABLE VIII

Finally, after studying the relationships between outsourcing risks and the percentage of the budget each firm allocates to IS, we have checked that no statistical relationship exists. In other words, these risks are not directly related to that budget percentage, as can be verified in Table IX.

\section{Take in TABLE IX}

\section{SUMMARY AND CONCLUSIONS}

IS outsourcing has become a widespread phenomenon worldwide, and is also very common among large Spanish firms. Despite their large size (in terms of both sales and number of employees), and judging by the staff volume of IS departments and the part of the budget allocated to IS activities, these firms do not dedicate many resources to IS services.

The main obstacle mentioned by the largest Spanish firms in relation to IS outsourcing is the excessive dependence on the provider this type of contract can generate. Other important fears, although less significant than the previous one, would be the loss of competence the customer may suffer and the dubious qualification of the provider's staff. Curiously enough, the risk ranked lowest in importance is the inability to adapt to new technologies, which suggests that doubts refer to providers' personal or human characteristics rather than to their technical skills. Another surprising result is the low 
ranking for possible IS staff opposition, which clearly contrasts with the importance given to this factor in the literature.

Nevertheless, we can find an explanation if we relate these risks to some of the characteristics of the interviewed firms and their IS departments. Thus, it can be seen that the most important problem involved in outsourcing (excessive dependence on the provider) is mainly associated with the firms that outsource the most, are smaller (in terms of both sales and number of employees) and have fewer IS staff, whereas larger firms outsourcing the most are particularly concerned about their own staff 's opposition to this type of contract. In the former case, it seems reasonable for smaller firms to have objections to this potential dependence, since they have not so many resources available to abandon the provider and look for other alternatives (like the internal reconstruction of their own IS department or the search for new providers). In the latter case, it could be argued that firms which outsource the most and are larger in size fear the opposition of their staff due to the large number of employees that might be affected by outsourcing.

As for the loss of skills and competences, the risk ranked second in importance, it is the most frequent among firms with more resources (in terms of sales and IS staff), which would mean that these firms' most important concern is their own incompetence once outsourcing has been introduced. On the other hand, we can say that although there is clear evidence that outsourcing risks are determined by both outsourcing level and certain characteristics related to firm size (sales, number of employees and IS staff), it is also true that other characteristics, such as the activity sector or the budget percentage allocated to IS, do not condition those risks.

Finally, we must point out that the outsourcing risks described in this paper should be taken into account, both in business practice and in future theoretical developments, since all of them have found some support, at least in the firms we have analysed. In order to reduce those risks, IS managers should consider the possibility of not resorting 
to total outsourcing, choosing instead either selective outsourcing or a multiple-provider approach, or even both at the same time. Another interesting alternative would consist in the IS department's facing up to outsourcing providers' offers with a benchmarking study.

It becomes important in these contracts to make sure that customer-provider relationships are not only based on mutual trust and understanding (although they both are essential for any cooperation scheme). The relationship must be additionally based on a well-structured contract, and the customer firm must also be permanently vigilant about the delivery of the outsourced services. In any case, firms must be aware of the need to retain some specific key knowledge in house if they really want the outsourcing relationship to work satisfactorily for the customer.

\section{REFERENCES}

Alpar, P. and Saharia, A.N. (1995) "Outsourcing Information Systems Functions: an Organization Economics Perspective", Journal of Organizational Computing, Vol. 5 No 3, pp. 197-217.

Ang, S. ang Cummings, L.L. (1997) "Strategic Response to Institutional Influences on Information Systems Outsourcing", Organization Science, Vol. 8 No 3, pp. 235-256.

Aubert, B.A., Rivard, S. and Patry, M.A. (1996) "Transaction Cost Approach to Outsourcing Behavior: Some Empirical Evidence", Information \& Management, Vol. 30 No 2, pp. 51-64.

Baldwing, L.P., Irani, Z. and Love, P. (2001) "Outsourcing Information Systems: Drawing Lessons from a Banking Case Study", European Journal of Information Systems, Vol. 10 No 1, pp. 15-24.

Barthélemy, J. (2001) "The Hidden Cost of IT Outsourcing", MIT Sloan Management Review, Vol. 42 No 3, pp. 60-69.

Chen, Q. and Lin, B. (1998) "Global Outsourcing and its Managerial Implications", Human Systems Management, Vol. 17 No 2, pp. 109-114.

Ching, Ch., Holsapple, C.W. and Whinston, A.B. (1996) "Toward IT Support for Coordination in Network Organizations", Information \& Management, Vol. 30 No 4, pp.179-199.

Clark, T.D., Zmud, R.W. and McCray, G.E. (1995) "The Outsourcing of Information Services: Transforming the Nature of Business in the Information Industry", Journal of Information Technology, Vol. 10, pp. 221-237.

Collins, J.S. and Millen, R.A. (1995) "Information Systems Outsourcing by Large American Industrial Firms: Choices and Impacts", Information Resources Management Journal, Vol. 8 No 1, pp. 5-13.

Corbett, M.F. (1994) "Outsourcing and the New IT Executive. A Trends Report", Information Systems Management, Vol. 11 No 4, pp. 19-22.

Cross, J. (1995) “IT Outsourcing: British Petroleum's Competitive Approach”, Harvard Business Review, May-June, pp. 94-102.

Currie, W.L. (1998) "Using Multiple Suppliers to Mitigate the Risk of IT Outsourcing at ICI and Wessex Water", Journal of Information Technology, Vol. 13 No 3, pp. 169-180. 
Currie, W.L. and Seltsikas, P. (2001) "Exploring the Supply-side of IT Outsourcing: Evaluating the Emerging Role of Application Service Providers", European Journal of Information Systems, Vol. 10, pp. 123-134.

Currie, W.L. and Willcocks, L.P. (1998) "Analysing Four Types of IT Sourcing Decisions in the Context of Scale, Client/supplier Interdependency and Risk Mitigation", Information Systems Journal, Vol. 8 No 2, pp. 119-143.

Earl, M.J. (1996) "The Risk of Outsourcing IT", Sloan Management Review, Vol. 37 No 3, pp. 26-32.

Fink, D. (1994) "A Security Framework for Information Systems Outsourcing", Information Management \& Computer Security, Vol. 2 No 4, pp. 3-8.

Fink, D. and Shoeib, A. (2003) "Action: the most critical phase in outsourcing information technology", Logistics Information Management, Vol. 16 No 5, pp. 302-311.

Fowler, A. and Jeffs, B. (1998) "Examining Information Systems Outsourcing: A Case Study from The United Kingdom", Journal of Information Technology, Vol. 13 No 2, pp. 111-126.

Glass, R.L. (1996) "The End of the Outsourcing Era", Information Systems Management, Vol. 13 No 2, pp. 89-91.

Grover, V., Cheon, M.J. and Teng, T.C. (1994) "A Descriptive Study on the Outsourcing of Information Systems Functions", Information \& Management, Vol. 27 No 1, pp. 3344.

Grover, V. and Teng, J.T.C. (1993) "The decision to outsource information systems functions", Journal of Systems Management, November, pp. 34-38.

Gupta, G. and Gupta, H. (1992) "Outsourcing the IS Function. Is It Necessary for your Organization?”, Information Systems Management, Vol. 9 No 3, pp. 44-50.

Guterl, F. (1996) "How to Manage your Outsourcer?", Datamation, Vol. 42 No 5, pp. 79-83.

Heecks R. et al. (2001) "Synching or Sinking: Global Software Outsourcing Relationships", IEEE Software, Vol. 18 No 2, pp. 54-60.

Hirschheim, R. and Dibbern, J. (2002) "Information Systems Outsourcing in the New Economy - An Introduction", in: R. Hirschheim, A. Heinzl and J. Dibbern (Eds.), Information Systems Outsourcing. Enduring Themes, Emergent Patterns and Future Directions, Springer, Berlin, pp. 3-23.

Huber, R.L. (1993) "How Continental Bank Outsourced its «Crown Jewels »", Harvard Business Review, January-February, pp. 121-129.

Hurst, I. and Hanessian, B.G. (1995) "Navigating IT Channels: Integrate or Outsource?", The McKinsey Quarterly, Vol. 3, pp. 103-110.

Kearney, T. (2000) "Why Outsourcing is In", Strategic Finance, Vol. 81 No 9, pp. 34-38.

Kern, T. and Willcocks, L.P. (2000) "Exploring Information Technology Outsourcing Relationship: Theory and Practice", Journal of Strategic Information Systems, Vol. 9 No 4, pp. 321-350.

Kern, T. and Willcocks, L.P. (2002) "Exploring Relationships in Information Technology Outsourcing: The Interaction Approach", European Journal of Information Systems, Vol. 11 No 1, pp. 3-19.

Ketler, K. and Walstrom, J. (1993) "The Outsourcing Decision", International Journal of Information Management, Vol. 13 No 6, pp. 449-459.

King, W.R. (2001) "Developing a Sourcing Strategy for IS: A Behavioral Decision Process and Framework" IEEE Transactions on Engineering Management, Vol. 48 No 1, pp. $15-24$.

Lacity, M.C. and Hirschheim, R. (1993a) "Implementing Information Systems Outsourcing: Key Issues and Experiences of an Early Adopter", Journal of General Management, Vol. 19 No 1, pp. 17-31.

Lacity, M.C. and Hirschheim, R. (1993b) "The Information Systems Outsourcing Bandwagon", Sloan Management Review, Vol. 35 No 1, pp. 73-86.

Lacity, M.C. and Willcocks, L.P. (1995) "Interpreting Information Technology Sourcing Decisions from a Transaction Cost Perspective: Findings and Critique", Accounting, Management \& Information Technology, Vol. 5 No 3/4, pp. 203-244.

Lacity, M.C. and Willcocks, L.P. (1997) "Information Systems Sourcing: Examining the Privatization Option in USA Public Administration", Information Systems Journal, Vol. 7 No 2, pp. 85-108.

Lacity, M.C., Willcocks, L.P. and Feeny, D.F. (1996) "The Value of Selective Sourcing", Sloan Management Review, Vol. 37 No 3, pp. 13-25. 
Loebbecke, C. and Jelassi, T. (1999) "Business Strategies and IT Outsourcing: The Case of Compunet AG", European Management Journal, Vol. 17 No 6, pp. 615-624.

Loh, L. and Venkatraman, N. (1992) "Determinants of Information Technology Outsourcing: A cross-sectional Analysis", Journal of Management Information Systems, Vol. 19 No 1, pp. 7-28.

Marchand, N. and Jacobsen, H.A. (2001) "An Economic Model to Study Dependencies between Independent Software Vendors and Application Service Providers", Electronic Commerce Research, Vol. 1 No 3, pp. 315-334.

Martinsons, M.G. (1993) "Outsourcing Information Systems: A Strategic Partnership with Risk", Long Range Planning, Vol. 26 No. 3, pp. 18-25.

McLellan, K., Marcolin, B. and Beamish, P. (1995) "Financial and Strategic Motivations behind IS Outsourcing", Journal of Information Technology, Vol. 10 No 4, pp. 299-321.

Moran, N. (1999) "Change in Sentiment over IT Outsourcing", Financial Times Survey, 4/8/1999, p. 1.

Palvia, P.C. (1995) "A Dialectic View of Information Systems Outsourcing: Pros and Cons", Information \& Management, Vol. 29 No 5, pp. 265-275.

Poppo, L. and Zenger, T. (1998) "Testing Alternative Theories of The Firm: Transaction Cost, Knowledge-Based, and Measurement Explanations for Make-or-Buy Decisions in Information Services", Strategic Management Journal, Vol. 19 No 9, pp. 853-877.

Smith, M.A. (2002) "Application Service Provision: The IS Infrastructure Context", in: R. Hirschheim, A. Heinzl and J. Dibbern (Eds.), Information Systems Outsourcing. Enduring Themes, Emergent Patterns and Future Directions, Springer, Berlin, pp. 451-473.

Tayntor, Ch.B. (2001) "A Practical Guide to Staff Augmentation and Outsourcing", Information Systems Management, Vol. 18 No 1, pp. 84-91.

Teng, J.T.C., Cheon, M.J. and Grover, V. (1995) "Decision to outsource Information systems functions: testing a strategy-theoretic discrepancy model", Decision Sciences, Vol. 26 No 1, pp. 75-103.

The Yankee Group (2003) Yankee Group releases (Internet publication). URL: http://www.yankeegroup.com/public/News, February, 27.

Willcocks, L.P. and Choi, Ch.J. (1995) "Co-operative Partnership and 'Total' IT Outsourcing: From Contractual Obligation to Strategic Alliance?" European Management Journal, Vol. 13 No 1, pp. 76-78.

Willcocks, L.P. and Fitzgerald, G. (1996) "IT Outsourcing and the Changing Shape of the Information Systems Function", in: Earl, M.J. (Ed.), Information Management. The Organizational Dimension, Oxford University Press, Oxford, pp. 270-294

Willcocks, L.P., Fitzgerald, G. and Lacity, M.C. (1996) "To Outsource or not? Recent Research on Economics and Evaluation Practice", European Journal of Information Systems, Vol. 6 No 5, pp. 143-160.

Willcocks, L.P. and Lacity, M.C. (1999) "IT Outsourcing in Insurance Services: Risk, Creative Contracting and Business Advantage", Information Systems Journal, Vol. 9 No 3, pp. 163-180.

Willcocks, L.P., Lacity, M.C. and Kern, T. (1999) "Risk Mitigation in IT Outsourcing Strategy Revisited: Longitudinal Case Research at LISA", Journal of Strategic Information Systems, Vol. 8 No 3, pp. 285-314.

Willcocks, L.P., Lacity, M.C. and Fitzgerald, G. (1995) "Information Technology Outsourcing in Europe and the USA: Assessment Issues", International Journal of Information Management, Vol. 15 No 5, pp. 333-351.

Yang, Ch. and Huang, J-B. (2000) "A decision model for IS outsourcing", International Journal of Information Management, Vol. 20 No 3, pp. 225-239.

\section{APPENDIX: Questionnaire}

\section{Which percentage of the following activities is carried out through outsourcing?}

Percenta
ge

Porcenta

ge 


\begin{tabular}{|c|c|}
\hline$\%$ & Applications analysis \\
\hline$\%$ & Support to end users \\
\hline$\%$ & Staff and/or user training \\
\hline$\%$ & Systems implementation \\
\hline$\%$ & Hardware maintenance \\
\hline$\%$ & Software maintenance \\
\hline
\end{tabular}

\begin{tabular}{|r|l}
\hline$\%$ & Systems Operation \\
\hline$\%$ & Programming \\
\hline$\%$ & Security \\
\hline$\%$ & Network service \\
\hline$\%$ & E-business solutions \\
\hline$\%$ & Others (indicate) \\
\hline
\end{tabular}

\section{Put a tick on the three main causes for reservations appearing when the time arrives to decide whether to outsource or not.}

Hidden costs in the contract

Qualification of provider's staff

A great dependence on the provider

The provider does not comply with the contract

The provider's inability to quickly adapt to new technologies

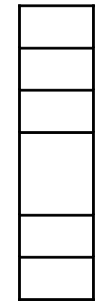

Irreversibility of the outsourcing decision Loss of critical skills and competences A possible opposition of our IS staff Security issues

Unclear cost-benefit relationship Others (show)

The organization's profile and the Information Systems Department's profile

3. The organization's size (year 2000) and its age.

Staff

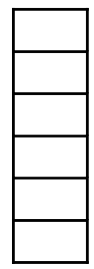

$0-50$

$51-100$

$101-500$

$501-1,000$

$1.001-25,000$

More than 25,000
Sales (billions of pesetas*)

Until 5

Between 6 and 10

Between 11 and 15

Between 16 and 25

Between 26 and 50

Between 51 and 100

More than 100

* One euro equals 166.386 pesetas

\section{Sector}

\section{Profile of the Information Systems Department/Service (in the year 2000).}

IS department's staff

Workers

Department's date of creation

Department's name

Percentage of the budget allocated to IS in relation to the organization's total budget 
Table I: Study technical specifications

\begin{tabular}{ll}
\hline Scope & Spain \\
Population & 4,416 largest Spanish business \\
Sample size & (by sales) \\
Sampling error & $5 \%$ valid answers (8\%) \\
Surveydate & June-October, 2001 \\
\hline
\end{tabular}

Table II: General characteristics of the firms

\begin{tabular}{|c|c|c|}
\hline Outsourcing & $\mathrm{N}$ & $\%$ \\
\hline No & 51 & 14.3 \\
\hline Yes & 306 & 85.7 \\
\hline \multicolumn{3}{|l|}{ Outsourcing Level } \\
\hline Below the mean & 175 & 49.0 \\
\hline \multicolumn{3}{|l|}{ Staff } \\
\hline $0-50$ & 22 & 6.2 \\
\hline $51-500$ & 202 & 56.6 \\
\hline More than 500 & 132 & 36.9 \\
\hline Lost & 1 & 0.3 \\
\hline \multicolumn{3}{|l|}{ Sales (billions of pesetas*) } \\
\hline Up to 5 & 36 & 10.1 \\
\hline More than 5 and up to 50 & 227 & 63.6 \\
\hline More than 50 & 93 & 26.0 \\
\hline Lost & 1 & 0.3 \\
\hline \multicolumn{3}{|l|}{ Sector } \\
\hline Industry & 210 & 58.8 \\
\hline Services & 118 & 33.1 \\
\hline $\begin{array}{c}\text { Financial and insurance institutions } \\
\text { IS staff }\end{array}$ & 29 & 8.1 \\
\hline 1-10 Employees & 240 & 67.2 \\
\hline 11-100 Employees & 96 & 26.9 \\
\hline 101-400 Employees & 5 & 1.4 \\
\hline Lost & 16 & 4.5 \\
\hline Budget percentage allocated to IS & & \\
\hline $0-4$ & 133 & 37.2 \\
\hline $5-10$ & 61 & 17.1 \\
\hline $11-30$ & 18 & 5.1 \\
\hline Lost & 145 & 40.6 \\
\hline
\end{tabular}


Table III: Outsourcing risks

\begin{tabular}{lrrc}
\hline \multicolumn{1}{c}{ Risks } & N & \% valid & Rank \\
\hline An excessive dependence on the & 189 & 61.8 & $1 \mathrm{st}$ \\
provider & 112 & 36.6 & 2nd \\
Loss of critical skills and competences & 110 & 35.9 & 3rd \\
Qualification of the provider's staff & 101 & 33.0 & 4 th \\
The provider does not comply with the & 94 & 30.7 & 5 th \\
contract & 90 & 29.4 & 6 th \\
Unclear cost-benefit relationship & 63 & 20.6 & 7 th \\
Hidden costs in the contract & 30 & 9.8 & 8th \\
Security issues & 22 & 7.2 & 9 th \\
Irreversibility of the outsourcing & 19 & 6.2 & 10 th \\
decision & & & \\
The possible opposition of our IS staff & & & \\
Inability to adapt to new technologies & & & \\
\hline
\end{tabular}

Table IV: Chi-square test: outsourcing level and outsourcing risks

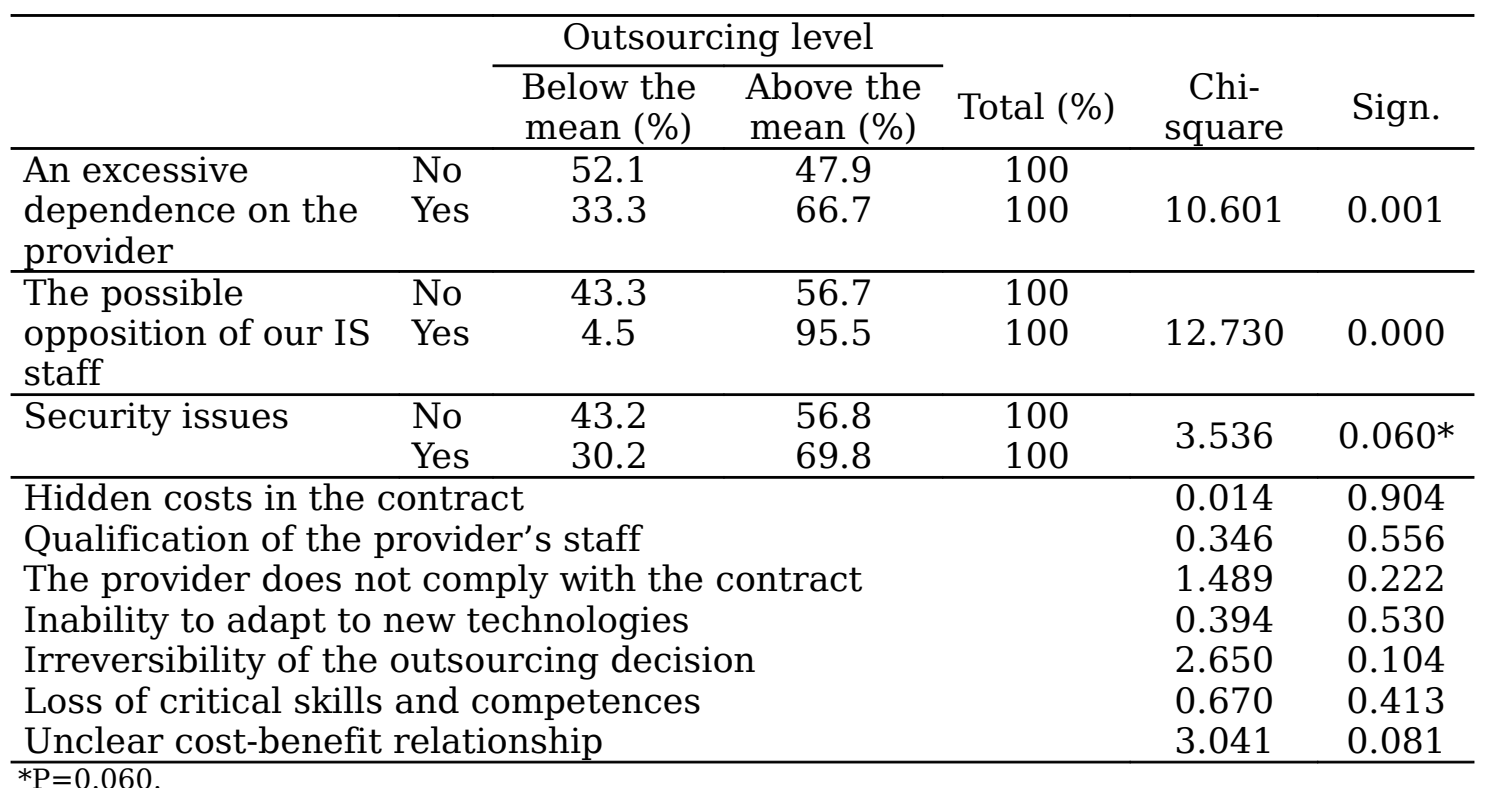

Table V: Chi-square test: staff and outsourcing risks

\begin{tabular}{|c|c|c|c|c|c|c|}
\hline & \multicolumn{2}{|c|}{ Staff } & \multirow[b]{2}{*}{$\begin{array}{c}\text { Total } \\
(\%)\end{array}$} & \multirow[b]{2}{*}{ Chi-square } & \multirow[b]{2}{*}{ Sign. } \\
\hline & & $\begin{array}{l}\text { Up to } 500 \\
(\%)\end{array}$ & $\begin{array}{c}\text { From } 500 \\
(\%)\end{array}$ & & & \\
\hline Qualification of the & No & 67.3 & 32.7 & 100 & & \\
\hline provider's staff & Yes & 52.7 & 47.3 & 100 & 6.398 & 0.011 \\
\hline An excessive & No & 49.6 & 50.4 & 100 & & \\
\hline $\begin{array}{l}\text { dependence on the } \\
\text { provider }\end{array}$ & Yes & 60.8 & 30.2 & 100 & 12.613 & 0.000 \\
\hline The possible & No & 64.8 & 35.2 & 100 & & \\
\hline $\begin{array}{l}\text { opposition of our IS } \\
\text { staff }\end{array}$ & Yes & 27.3 & 72.7 & 100 & 12.209 & 0.000 \\
\hline Security issues & $\begin{array}{l}\text { No } \\
\text { Yes }\end{array}$ & $\begin{array}{l}59.3 \\
73.0\end{array}$ & $\begin{array}{l}40.7 \\
27.0\end{array}$ & $\begin{array}{l}100 \\
100\end{array}$ & 4.022 & 0.045 \\
\hline $\begin{array}{l}\text { Unclear cost-benefit } \\
\text { relationship }\end{array}$ & $\begin{array}{l}\text { No } \\
\text { Yes }\end{array}$ & $\begin{array}{l}67.9 \\
48.9\end{array}$ & $\begin{array}{l}32.1 \\
51.1\end{array}$ & $\begin{array}{l}100 \\
100\end{array}$ & 9.976 & 0.002 \\
\hline
\end{tabular}


Hidden costs in the contract

0.650

0.420

The provider does not comply with the contract

0.679

0.410

Inability to adapt to new technologies

0.152

Irreversibility of the outsourcing decision

0.062

0.697

Loss of critical skills and competences 
Table VI: Chi-square test: sales and outsourcing risks

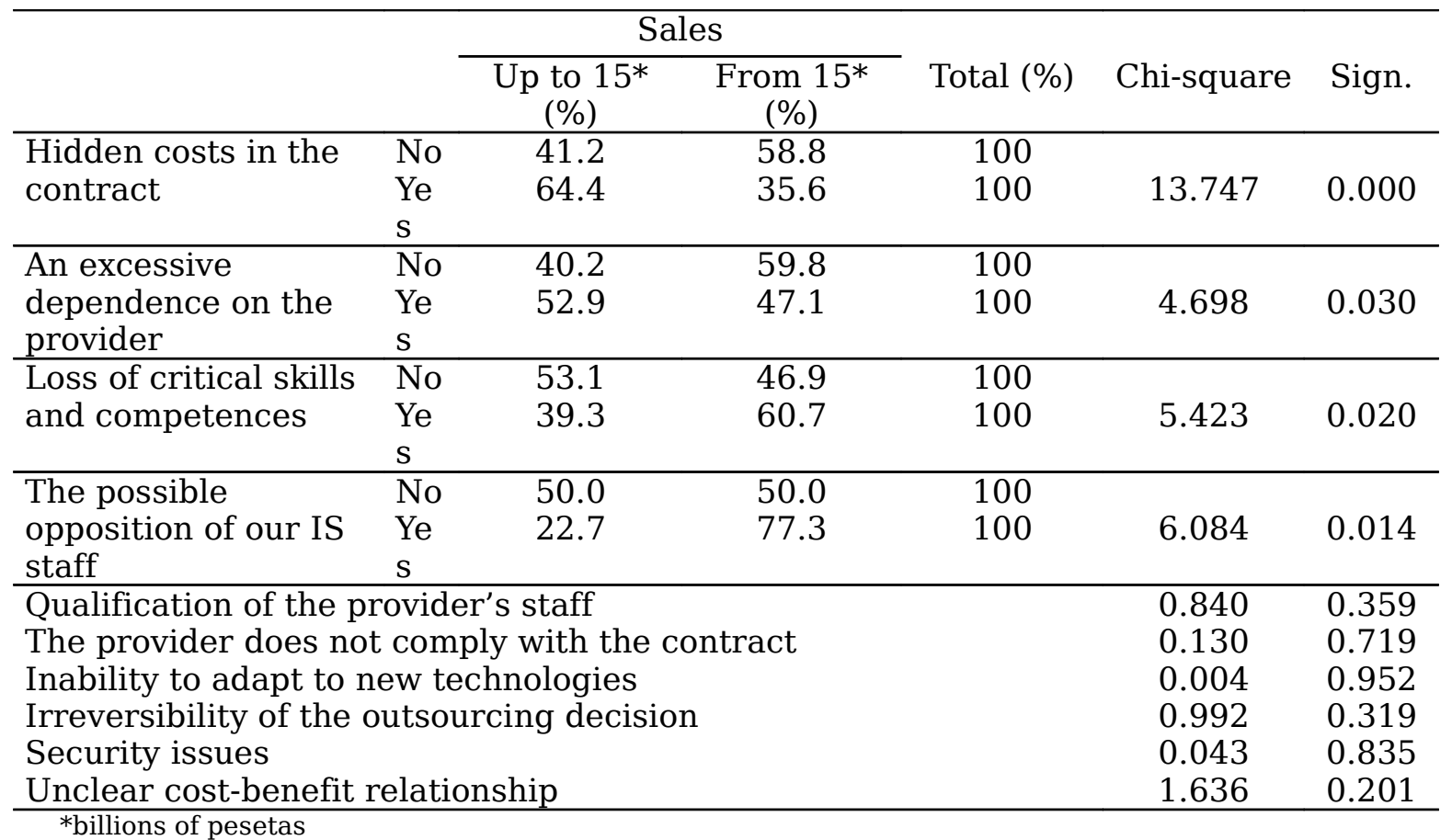

Table VII: Chi-square test: sector and outsourcing risks

\begin{tabular}{lcc}
\hline & Chi-square & Sign. \\
\hline Hidden costs in the contract & 2.286 & 0.319 \\
Qualification of the provider's staff & 0.975 & 0.614 \\
An excessive dependence on the & 0.181 & 0.914 \\
provider & 1.099 & 0.577 \\
The provider does not comply with & 0.198 & 0.906 \\
the contract & 1.765 & 0.414 \\
Inability to adapt to new technologies & 2.227 & 0.328 \\
Irreversibility of the outsourcing & 0.024 & 0.988 \\
decision & 1.320 & 0.517 \\
Loss of critical skills and competences & 4.679 & 0.096 \\
The possible opposition of our IS staff & & \\
Security issues & & \\
Unclear cost-benefit relationship & & \\
\hline
\end{tabular}

Table VIII: Chi-square test: IS staff and outsourcing risks

\begin{tabular}{|c|c|c|c|c|c|c|}
\hline & \multicolumn{2}{|c|}{ IS Staff } & \multirow[b]{2}{*}{ Total (\%) } & \multirow[b]{2}{*}{ Chi-square } & \multirow[b]{2}{*}{ Sign. } \\
\hline & & $\begin{array}{c}\text { Up to } 5 \\
(\%)\end{array}$ & $\begin{array}{c}\text { From } 5 \\
(\%)\end{array}$ & & & \\
\hline An excessive & No & 31.0 & 69.0 & 100 & & \\
\hline $\begin{array}{l}\text { dependence on the } \\
\text { provider }\end{array}$ & Yes & 48.3 & 51.7 & 100 & 8.609 & 0.003 \\
\hline $\begin{array}{l}\text { Loss of critical skills } \\
\text { and competences }\end{array}$ & $\begin{array}{l}\text { No } \\
\text { Yes }\end{array}$ & $\begin{array}{l}46.0 \\
34.0\end{array}$ & $\begin{array}{l}54.0 \\
66.0\end{array}$ & $\begin{array}{l}100 \\
100\end{array}$ & 4.027 & 0.045 \\
\hline $\begin{array}{l}\text { Unclear cost-benefit } \\
\text { relationship }\end{array}$ & $\begin{array}{l}\text { No } \\
\text { Yes }\end{array}$ & $\begin{array}{l}45.8 \\
32.2\end{array}$ & $\begin{array}{l}54.2 \\
67.8\end{array}$ & $\begin{array}{l}100 \\
100\end{array}$ & 4.739 & 0.029 \\
\hline
\end{tabular}


Hidden costs in the contract

1.364

0.243

Qualification of the provider's staff

$0.765 \quad 0.382$

The provider does not comply with the contract

0.262

0.609

Inability to adapt to new technologies

0.275

0.600

Irreversibility of the outsourcing decision

0.584

0.445

The possible opposition of our IS staff

0.944

0.331

Security issues

0.303

0.582 
Table IX: Chi-square test: Budget percentage allocated to IS and outsourcing reasons

\begin{tabular}{lcc}
\hline & Chi-square & Sign. \\
\hline Hidden costs in the contract & 1.591 & 0.207 \\
Qualification of the provider's staff & 0.507 & 0.476 \\
An excessive dependence on the & 0.008 & 0.927 \\
provider & 0.685 & 0.408 \\
The provider does not comply with the & 0.601 & 0.438 \\
contract & 0.177 & 0.674 \\
Inability to adapt to new technologies & 0.130 & 0.719 \\
Irreversibility of the outsourcing & 1.593 & 0.207 \\
decision & 1.058 & 0.304 \\
Loss of critical skills and competences & 0.407 & 0.523 \\
The possible opposition of our IS staff & & \\
Security issues & & \\
Unclear cost-benefit relationship & & \\
\hline
\end{tabular}

